\title{
【論文】
}

\section{ウェアラブル徘徊高齢者介護支援システムの提案 A wearable Care Support System for Wandering Elderly Persons}

\author{
松岡 伸吾(学生会員),小川 英邦*(正会員),槇 弘倫*(正会員), \\ 米沢 良治*(非会員) \\ Shingo Matsuoka, Hidekuni Ogawa*, Hiromichi Maki*, \\ Yoshiharu Yonezawa*
}

\begin{abstract}
A wearable care support system has been developed for transmitting information of a wandering elderly person's location, environmental sounds and posture. The system consists of a wandering monitor device, a conventional desktop personal computer and a caregiver's mobile phone. The wandering monitor device, which is attached behind the neck of the person's shirt, is composed of a low transmitting power personal handy-phone system (PHS) module, a small microphone, an acceleration sensor and a one chip microcontroller. The wandering elderly person's location is identified by the PHS mobile phone company's base station via the PHS module. The caregiver sets the elderly person's safe resident area to the microcontroller. When the elderly person goes out of this area, the sensor automatically records the environmental sound around the wandering person, with the microphone, for 10 seconds. The PHS module sends the elderly person's location, the environmental sound and $\mathrm{Z}$ axis acceleration to the server computer. The server computer automatically informs the caregiver this information by e-mail. The caregiver can monitor the map of the wandering person's location and the sound via the Internet. The sound enables the presumption of a place and the situation of the elderly person.
\end{abstract}

\section{Key Words}

wandering elderly person, personal handy-phone system, environmental sound, posture, caregiver

\section{1. はじめに}

日本における認知症の推計高齢者数は,2007年の厚生 労働白書 ${ }^{1)}$ によると 2010 年に約 200 万人,2030年には 350

2011 年 11 月 29 日受理

2012 年 2 月 20 日最終原稿受理

トリニティカレッジ広島医療福祉専門学校, 広島県広島市

* 広島工業大学, 広島県広島市

International Trinity College, Hiroshima-city, Hiroshima

* Hiroshima Institute of Technology, Hiroshima-city, Hiroshima
万人を超えると予想されている.認知症高齢者は, 認知症が 長期的かつ進行性の疾患であることから新たな生活習慣だ けでなく,それまでの生活習慣をも徐々に失ってしまう.認知 症で特に問題となる症状として,目的地や現在地が分からな いまま移動し続ける徘䧃行為がある.徘徊行為は, 高齢者が 事故に遭う可能性や,行方不明になる危険性があるだけでな く,介護する家族やホームヘルパーなどの介護者に大きな精 神的負担 ${ }^{2-3)}$ を与えてしまう.そこで,屋内に設置した種々の センサで徘徊高齢者が屋外に出たことを検知するシステム 4-9)方研究開発されている.しかし, 早期保護が出来ない場合, 徘徊高齢者の徘徊状況や位置を検出出来ない問題がある. 
この問題に対し,徘徊高齢者へglobal positioning system (GPS)やpersonal handy-phone system (PHS) モジュー ルを装着し, 屋外での徘徊高齢者の位置を取得するシステム 10-17)が開発されている. 現在,GPSモジュールを用いた装置 は, 約 $10 \mathrm{~m}$ の精度で位置を特定できるが, 室内や地下街の場 所において位置情報を取得することが出来ない問題がある. 更に,GPSモジュールは, 通信機能を有さないため, 取得した 位置情報を介護者に通報する携帯電話を必要とする。一 方,PHSモジュールは,データ通信機能を有していると同時 に, 位置情報の取得も可能である.PHSモジュールによる位 置情報は,設置されたPHS基地局の緯度・経度で得られるこ とから,屋内や地下街などにおいてもPHS基地局が設置され ていれば,位置の特定が可能である利点を有している.しかし， 得られる位置情報は, 徘徊高齢者の位置,PHS基地局の設 置状況及びPHSのアクセス状況によって変動し, 誤差が数 $100 \mathrm{~m}$ から $1 \mathrm{~km}$ 程度となる場合もある. 現在, GPSやPHSを 利用した子供や高齢者の位置把握システムとして,どこ・イル 力 $(81 \mathrm{mmx} 46.5 \mathrm{mmx} 19.8 \mathrm{~mm}, 45 \mathrm{~g})$ 18) やココセコム $(79 \mathrm{mmx} 43 \mathrm{mmx} 22.5 \mathrm{~mm}, 53 \mathrm{~g}){ }^{19)}$ が商品化されている.こ れらのシステムは,携帯電話程度の形状と質量をもつ装置を 利用者に携帯させ,その利用者の位置を家族など登録して いる介護者が必要に応じて確認することが出来る.しかし, 新 たな生活習慣を身につけることが難しい認知症高齢者が, 外 出時に装置を忘れずに携帯することは非常に困難である.ま た,携帯電話程度の形状と質量をもつこれらの装置を介護者 が認知症高齢者の服のポケットに入れたり, 服に縫い付けた り, 首からぶら下げたりした場合, 認知症高齢者は, 違和感を 感じると外してしまう可能性がある.更に,これらのシステムで 得られる情報は位置情報のみであるため, 徘徊高齢者が危 険な場所にいるのか倒れていないか等, 徘徊高齢者の家族 や介護者にとって重要な徘䧃状況を知ることが出来ない.

そこで本研究は, 徘徊高齢者の位置情報だけでなく,徘徊 状況の把握に重要な徘徊高齢者の姿勢,どのような場所で どのような状態でいるかの推定を可能にする周囲環境音 20-22)を同時取得するウェアラブル徘徊高齢者介護支援シス テムを提案する.本システムは,あらかじめ設定した居住エリ ア外に徘徊高齢者が出た場合, 位置情報の取得と同時に, 徘徊高齢者周囲の環境音と姿勢を家族や介護者に通報す る.これらの動作は,徘徊高齢者自身による装置の操作を必 要とせず,全て自動的に行われる.また, 装置は, 徘徘徊高齢 者の手が届き難く, 衣服を脱ぐ以外装置を取り外すことがな いよう衣類背面のポケットに装着され, 装着に対する装置の 意識を出来るだけ軽減させる. 本システムは, 位置情報, 姿勢 及び環境音によって, 徘徊状況の遠隔モニタリングを可能に し, 徘徊高齢者の介護支援と共に,介護者の精神的負担を軽 減させることを目的とした。

\section{2. システム構成}

Fig.1にシステム構成図を示す.本システムは,位置情報,
周囲環境音, 姿勢状態を測定するセンサと処理, 通信機能を 一体型にした徘徊高齢者が装着可能な小型・軽量の徘徊モ ニタ装置,介護施設に設置するサーバーコンピュータ, 徘徊 高齢者の家族や介護者が携帯するフルブラウザ搭載の携帯 電話で構成した.徘䧃モニタ装置で取得した情報は, 通信回 線を利用して,サーバーコンピュータへ自動送信される.サー バーコンピュータは, 徘徊モニタ装置から送られた徘徊高齢 者の情報を電子メールで家族や介護者などの緊急連絡先 一自動送信する.家族や介護者は,携帯電話に送られてきた 徘徊高齢者の情報から徘䧃状況の遠隔モニタリングが可能 となる。

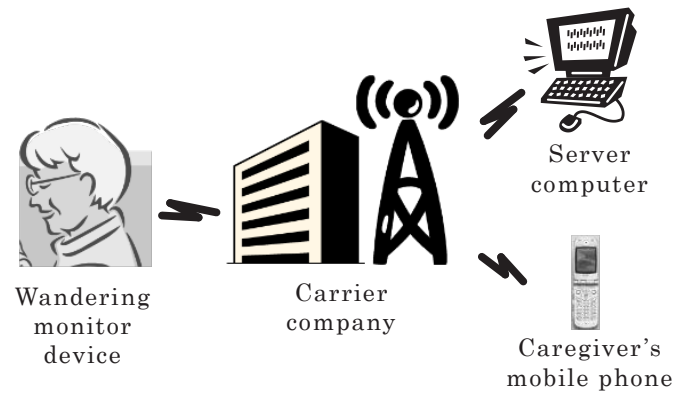

Fig.1 Overall of mobile-phone based safety support system.

Fig.2に徘徊モニタ装置のブロック図を示す.徘徊モニタ装 置はエレクトレットコンデンサマイクロフォン (Panasonic, WM-64PNT), 加速度センサ (Kionix, KXM52-1050), 増 幅器(Texas Instruments, OPA336), ローパスフィルタ,32 ビットマイクロコントローラ (Microchip,PIC32MX695F512H) 及びPHS モ゙ュール (Willcom, W-SIM RX430AL) で構成した.エレクトレットコン デンサマイクロフォンは, 直径 $5 \mathrm{~mm}$, 厚さ $1 \mathrm{~mm}$, 質量 $0.16 \mathrm{~g}$ の 無指向性マイクロフォンで, 徘徊時に徘徊高齢者周囲の環境 音を集音する.環境音は, 演算増幅器で構成した利得 $60 \mathrm{~dB}$ の 非反転増幅器により増幅される.加速度センサは,身体の上下 (Z軸)方向の大地に対する重力加速度を測定し, 遮断周波数 $0.5 \mathrm{~Hz}$ のローパスフィルタで臥位かどうかの判断を行う重力加 速度を取り出す.立位や座位状態において, 上体が大地に対 し垂直になると加速度センサに加わる重力加速度は $1 \mathrm{~g}$ となり, ローパスフィルタで1 $\mathrm{g}$ に対応した電圧が取り出される.一方, 倒 れた臥位状態において,上体が大地に対し平行になると重力 加速度は $0 \mathrm{~g}$ となり,立位・座位状態と異なった $0 \mathrm{~g}$ に対応した電 圧が取り出される.姿勢の判断 ${ }^{23}$ は, ローパスフィルタで取り出 された重力加速度に対応した電圧で行われ, 電圧変動がない 場合じっとしていると判断される.

増幅された環境音とZ軸の重力加速度は,マイクロコントロ 一ラ内蔵の 8 ビットAD変換器によりデジタルデータへ変換さ れる.サンプリング周波数は, 環境音を $8 \mathrm{kHz}$, 重力加速度を $50 \mathrm{~Hz}$ とした.PHSモジュールは,至近のPHS基地局の緯度と 経度を取得し,サーバーコンピュータへのデータ送信機能 


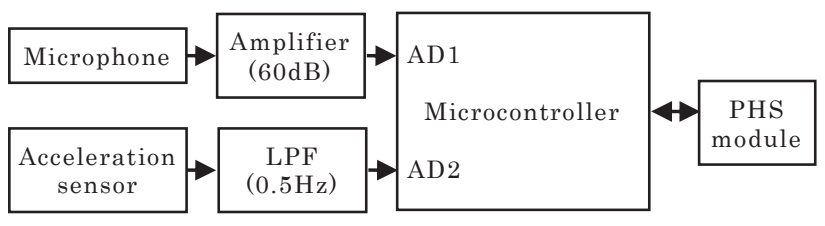

Fig.2 Block diagram of the wandering monitor device.

を持つ.形状は $42.0 \mathrm{~mm} \times 25.6 \mathrm{~mm} \times 4.0 \mathrm{~mm}$, 質量 $5 \mathrm{~g}$ である. マイクロコントローラは,あらかじめ設定した居住エリア外に俳 徊高齢者が出た場合,俳徊高齢者の位置, 環境音及び姿勢 を,PHSモジュールを介してサーバーコンピューター送信する ことで家族や介護者一の通報を可能とする.

Fig. 3 に徘徊モニ夕装置の外観を示す.装置の外形は $60 \mathrm{~mm} \times 38 \mathrm{~mm} \times 8 \mathrm{~mm}$ で, $3.7 \mathrm{~V}, 300 \mathrm{mAh}$ のリチウムポリマ 一バッテリー 1 個で駆動し,装置の総質量は $24.5 \mathrm{~g}$ である.装 置は 10 分毎の位置情報の取得で最大 36 時間の連続使用 が可能であるが,俳徊時の通報 1 回で $6.7 \mathrm{mAh}$ の電力量を消 費することから,通報回数により連続使用時間が低下寸る.

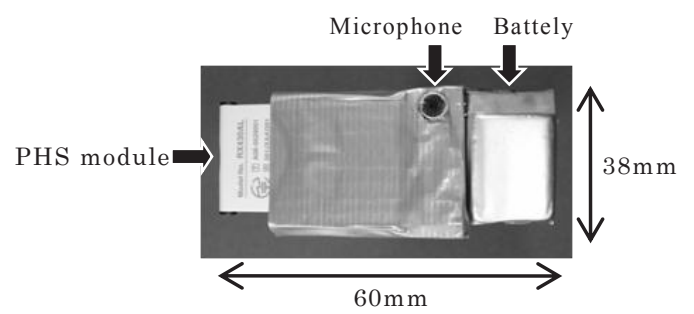

Fig.3 Appearance of the wandering monitor device.

徘徊モニタ装置は,Fig.4に示すよう徘徊高齢者の下着の 背中に取りつけたポケットに入れて装着される.背中への装 着は, 徘徊高齢者が俳䧃モニ夕装置を容易に取り外すことを 防ぎ,装着に対する意識と負担を軽減させる.

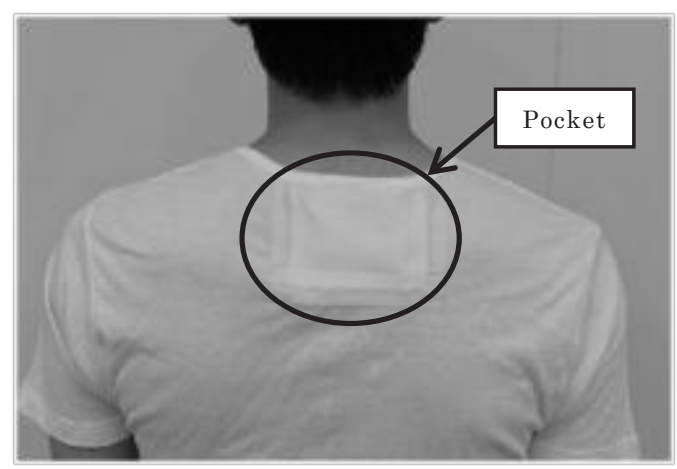

Fig.4 Pocket installed behind the neck of the wandering person.

Fig.5に徘䧃モニタ装置のフローチャートを示す.徘徊モ ニタ装置は,サーバーコンピュータで設定した徘徊高齢者が 居住するエリアをカバーするPHS基地局の緯度・経度を受 信する.徘䧃モニタ装置は, 10 分間毎にPHS基地局から取
得した位置と設定された緯度・経度とを比較する.取得した位 置が設定された緯度・経度内であれば,マイクロコントローラ は, 俳徊状態でないと判断し,PHSモジュールの電源を切り, 環境音や加速度の $\mathrm{AD}$ 変換を停止し,スリープ状態に移行す る.一方, 俳䧃状態であると判断した場合, 俳徊高齢者周囲の 環境音と重力加速度は 10 秒間 $\mathrm{AD}$ 変換され, 位置情報と共 に,PHSモジュールによりPHS公衆回線を介してサーバーコ ンピューター送信される。

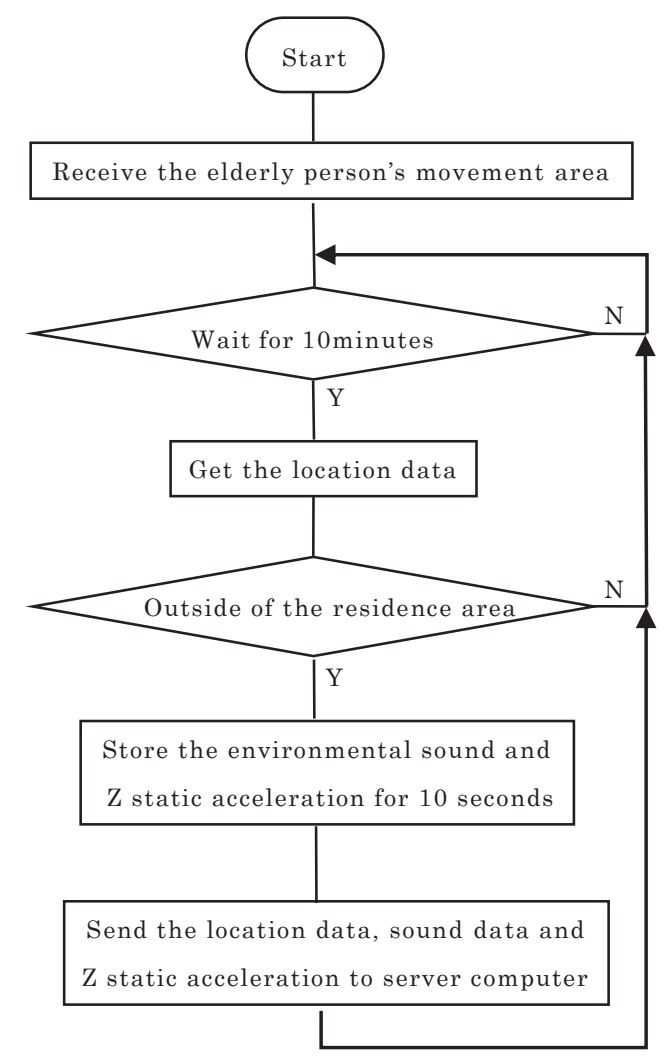

Fig.5 Flow chart of the wandering monitor device.

Fig.6にサーバーコンピュータのフローチャートを示す.サ ーバーコンピュータは,徘徊モニタ装置に徘徊高齢者の居住 エリアを送信した後,位置,環境音及び重力加速度を徘徊モ ニタ装置から受信するまで待機状態となる.サーバーコンピ ュータは,データを受信すると受信した日時をファイル名とし て格納する。

徘徊高齢者の位置を表示する地図として,Googleマップ 24)を利用した.Googleマップでは,緯度・経度に世界測位系 を採用しており,URLに緯度・経度を含めることで目的とする 位置を得ることができる.PHSモジュールで得られる緯度・経 度は日本測位系のため,世界測位系の緯度・経度に変換す る.変換した緯度・経度に合わせた地図の uniform resource locator（URL)が作成された後, その地図をダウ ンロードしサーバーコンピュータ画面に表示する.

徘徊モニタ装置から送信される環境音デー夕は,ファイル 容量が小さく,携帯電話で再生可能な $3 \mathrm{GP}$ 形式 25$)$ に変換さ 
れ,サーバーコンピュータに格納される.

高齢者の姿勢は,加速度センサで得られた身体の上下 $(\mathrm{Z}$ 軸)方向の重力加速度により求めた大地に対する傾斜角度 で,臥位か臥位でないか判断される.

サーバーコンピュータは, 徘徊高齢者の位置を示す地図 データを取得するURL, 地図画像, 音声ファイル及び姿勢を 電子メールで送信する.

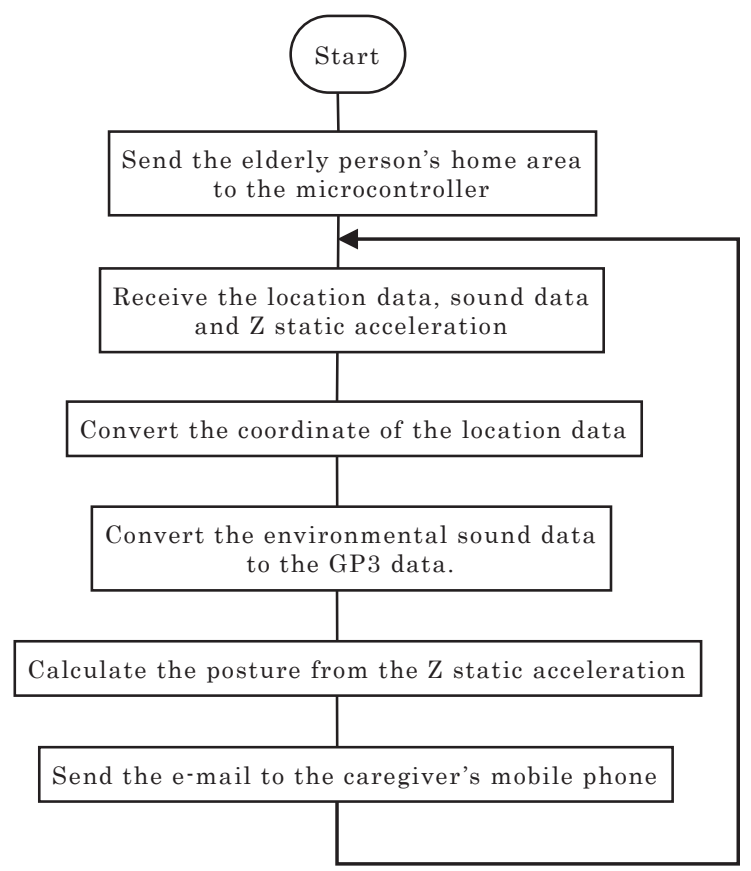

Fig.6 Flow chart of the server computer.

Fig.7にサーバーコンピュータの表示画面を示す.画面左 上には,データ受信日時,位置の緯度・経度,姿勢状態及び 音声情報の再生ボタンが表示される.徘徊高齢者の位置は, 地図上に数字のマーカで示され,マーカ(1)の最新の位置か ら,30分前の位置マーカ(4)まで順に表示される.尚,居宅位置 を示すマーカは“H”, 居住エリアを決めるPHS 基地局の位置 は“S”で表示される.最新の環境音は,音声情報の再生ボ夕 ンを押すと聞くことができる.全て取得した位置と環境音は,サ ーバーコンピュータ内に保存されており,必要に応じて履歴 を確認することが出来る.

Fig.8に介護者の携帯電話で受信した電子メール画面を 示す.Fig.8(a)に示す電子メール画面には, 姿勢,地図サイト から徘徊高齢者の位置をダウンロードするURL, 徘徊時の位 置の時間経過を示す地図及び環境音の音声ファイルが表 示されている.徘徊時の位置時間経過は最新の位置を中心 にし, $1 \mathrm{~km}$ 四方で表示されている.徘徊高齢者の位置をより 詳細に確認したい場合は,URLを選択し,Fig.8(b)に示すよ う徘徊高齢者の位置が中心にマークされた地図をダウンロ ードする.この地図はスケール変更が可能である.環

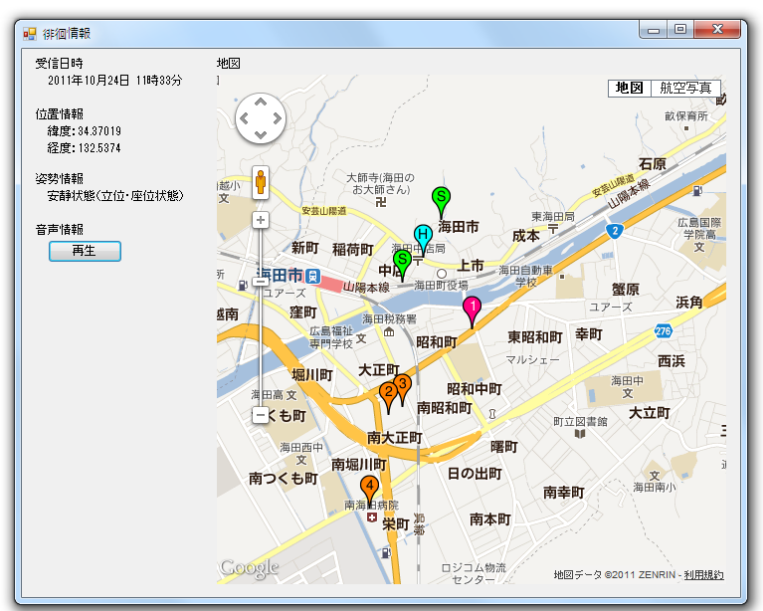

Fig. 7 Location information and sound file displayed on the server computer

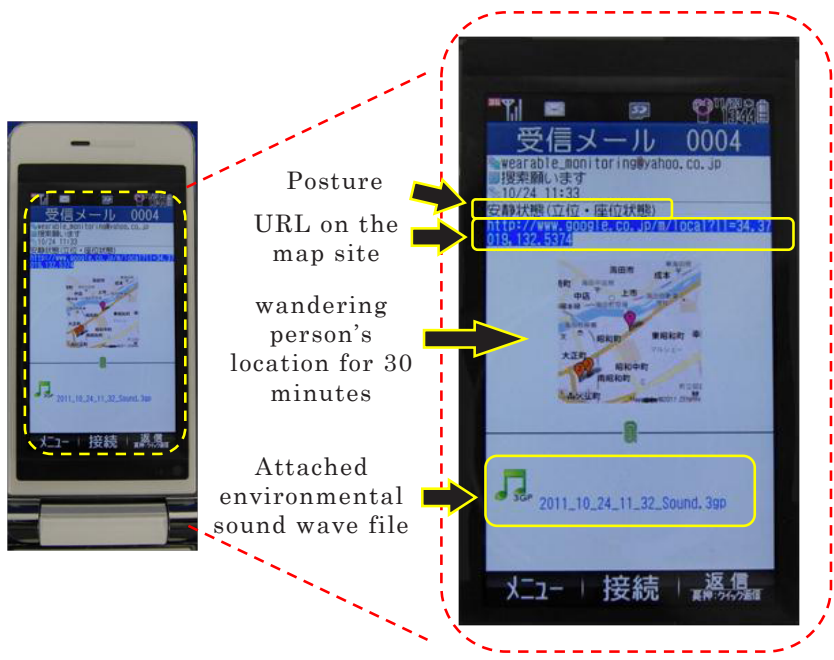

(a) Received e-mail displayed on the mobile phone.

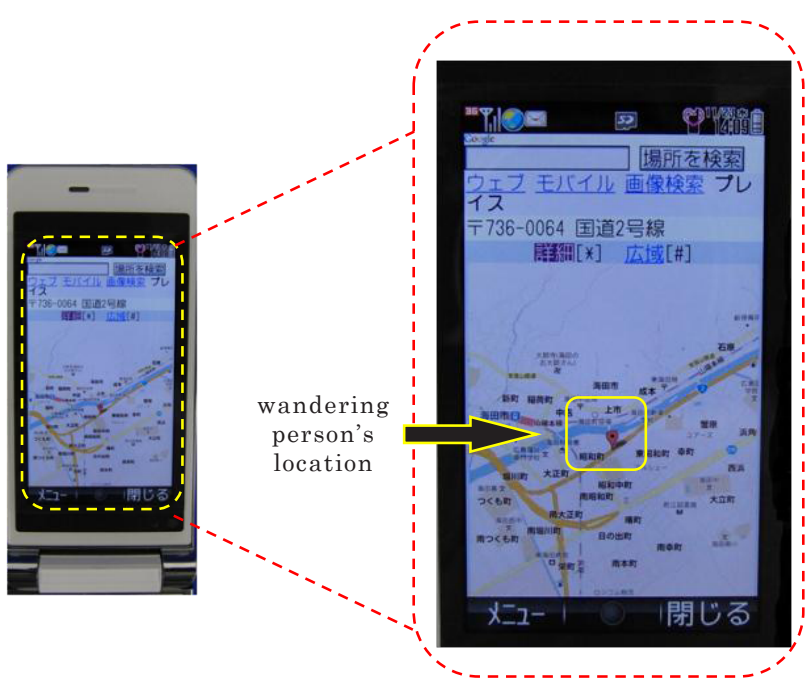

(b) Wandering person's location indicated by a red mark on the map.

Fig.8 Received e-mail and wandering person's location displayed on the caregiver's mobile phone. 


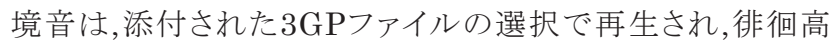
齢者が, 交通量の多い危険な場所にいるのか,スーパーマー ケットや静かで比較的安全な場所にいるのか等, 場所の推定 を可能にする.更に,環境音には, 俳徊高齢者が誰かと話して いるのか, 事故や怪我で苦しんでいるのか等の声が含まれ， 徘徊高齢者の徘徊状況の推定を可能にする.姿勢は, 徘徊 時に倒れているかどうかの確認を可能にする.本システムは, 徘徊中の高齢者の情報を 10 分毎に携帯電話で受信できる ことから,介護者による徘徊状況の遠隔モニタリングを可能に する.

\section{3. 実験方法}

本研究で提案した徘徊モニタ装置で取得した位置が,ど の程度の誤差を持っているかを検証した. 実験は, 広島市佐 伯区五日市の交通量の多い道路, 交通量の少ない道路, 公 園,スーパーマーケット及び踏切の場所で行ったこれらの場 所における測定点の緯度・経度は, 予めGoogleマップを用 いて設定した.サーバーコンピュータは大学内に設置され,介 護者が携帯する携帯電話としてフルブラウザ搭載の携帯電 話 (SoftBank, 936SH)を用いた.誤差は,設定した緯度・経 度と徘䧃モニ夕装置で得た緯度, 経度との差から求められた。 各測定場所では, 徘䧃モニ夕装置を東西南北方向に向け, 取 得した位置から最大誤差を求めた。

次に,位置情報を取得した測定場所における環境音から, 場所の推定が可能かの検証を行った. 被験者には, 車や電車 の走行音, 公園の子供の声, 店内アナウンスや踏切の警報音 などそれぞれの場所で取得した環境音を聞かせた.場所の 推定に必要な最適な環境音取得時間を決定寸るため, 健康 な20 22歳の男性 9 名に対して, 予備情報としての音や環 境音取得場所を知らせずそれぞれの環境音を 1 秒間, 3 秒 間, 5 秒間, 10 秒間, 15 秒間ランダムに再生し,場所の推定を 行わせた.環境音の再生は, 会話程度の音とし, 静かな室内で 行われた.実験で使用する環境音は, 学習効果が生じないよ う,それぞれ1回再生された.また,これらの結果が,被験者個 人の音の識別能力に依存することから, 取得した位置と 環境音を組み合わせることで正確な場所推定が可能かどう か実験を行った.被験者には, 最初に位置情報から得た地図 を見せ,次に環境音を 10 秒間聞かせて場所推定を行わせた。

最後に, 本システムが俳徊高齢者及び介護者にとって有 効であるかどうかの検証を行った.被験者は, 要介護認定を 受けていないが, 言動不一致や物忘れなど軽度の認知症状 を時折自覚する70歳の女性で行った. 尚,被験者と家族には, 本システムが俳徊状況の遠隔モニタリングが可能かどうか検 証する実験の趣旨と設定された居住エリア外に出た場合, 位 置の記録と周囲の環境音や本人の声が録音される点につい て詳細に説明し同意を得た.実験は,どのような行動も指示せ ず日常生活状態下で1週間に渡り行われた。

\section{4. 結果}

Table1に各測定場所での最大誤差を示す.この結果,最 大誤差は踏切で $1295 \mathrm{~m}$, 最小誤差は公園で $206 \mathrm{~m}$ であった.

Table1 Maximum location error in the various places

\begin{tabular}{|c|c|c|c|c|}
\hline $\begin{array}{c}\text { Heavy } \\
\text { traffic } \\
\text { road }\end{array}$ & $\begin{array}{c}\text { Light } \\
\text { traffic } \\
\text { load }\end{array}$ & $\begin{array}{c}\text { Public } \\
\text { park }\end{array}$ & Supermarket & $\begin{array}{c}\text { Railroad } \\
\text { crossing } \\
\text { in } \\
\text { railway }\end{array}$ \\
\hline 711 & 372 & 206 & 755 & 1295 \\
{$[\mathrm{~m}]$} & {$[\mathrm{m}]$} & {$[\mathrm{m}]$} & {$[\mathrm{m}]$} & {$[\mathrm{m}]$} \\
\hline
\end{tabular}

Table2 に環境音による場所の推定結果および環境音と 位置情報を組み合わせた場所の推定結果を示す.結果では, 再生時間が長くなるにつれ場所の正解率が上昇した.特に, 道路,踏切,スーパーマーケットなどでは,特徵的な環境音が あり,10秒を越えると $78 \%$ 以上の正解率で場所を推定するこ とが出来た.一方, 特徵的な音が少ない公園では, 15 秒間の 再生でも正解率が $100 \%$ とならなかった.しかし, 取得した位 置情報と環境音を組み合わせることで,全ての場所における 正解率は $100 \%$ となり,位置情報と環境音とを組み合わせる ことで正確な位置,場所推定が可能である結果が示された.

Table2 The ratio correctly identified by using the environmental sound and location information

\begin{tabular}{|c|c|r|r|r|r|r|}
\hline \multirow{2}{*}{ Experimental condition } & \multicolumn{5}{|c|}{ Place } \\
\hline \multirow{2}{*}{$\begin{array}{c}\text { Sound } \\
\text { reproduction } \\
\text { time }\end{array}$} & $\begin{array}{c}\text { Heavy } \\
\text { traffic } \\
\text { road }\end{array}$ & $\begin{array}{c}\text { Light } \\
\text { traffic } \\
\text { load }\end{array}$ & $\begin{array}{c}\text { Public } \\
\text { park }\end{array}$ & $\begin{array}{c}\text { Super } \\
\text { market }\end{array}$ & $\begin{array}{c}\text { Railroad } \\
\text { crossing } \\
\text { in } \\
\text { railway }\end{array}$ \\
\hline \multirow{2}{*}{$\begin{array}{c}\text { Environ- } \\
\text { mental } \\
\text { sound }\end{array}$} & $1 \mathrm{~s}$ & $44 \%$ & $44 \%$ & $0 \%$ & $33 \%$ & $56 \%$ \\
\cline { 2 - 7 } & $10 \mathrm{~s}$ & $100 \%$ & $89 \%$ & $56 \%$ & $78 \%$ & $100 \%$ \\
\cline { 2 - 7 } & $15 \mathrm{~s}$ & $100 \%$ & $100 \%$ & $78 \%$ & $89 \%$ & $100 \%$ \\
\hline $\begin{array}{c}\text { Location } \\
\text { information } \\
\text { and } \\
\text { environ- } \\
\text { mental } \\
\text { sound }\end{array}$ & $10 \mathrm{~s}$ & $100 \%$ & $100 \%$ & $100 \%$ & $100 \%$ & $100 \%$ \\
\hline
\end{tabular}

Fig. 9に本システムの有効性を検証するため70歳の女 性被験者 1 名で 1 週間にわたり取得した実験データから 求めた移動履歴の一部を示す.サーバーコンピュータの ディスプレイに表示された移動履歴は, 被験者が自宅 (Fig.9のHで表示) に近い2か所のPHS基地局（Fig.9のS で表示）の位置で設定した居住エリアを出て, 帰宅する までの10分毎に取得された位置で示されている.家族は, この間電子メールを受信し,被験者の位置と環境音で被験者 の状況を推定した.この結果, マーカ(4)の位置では, 被験者の 話している内容に「診察券」といら言葉が含まれていることか ら,容易に病院にいることを推定した.マーカ(3)の位置では, 環境音に店内の音楽が含まれており, 被験者が買い物中で 
あることを推定した.これらの結果は,当日の行動予定から確 認され,地図上に表示した位置と環境音から正確な位置の 把握が可能であることを示した.更に,家族は被験者が何処 で何をしているか推定でき, 家族の精神的負担が軽減された とシステムを評価した.一方, 被験者は, 俳䧃モニ夕装置の装 着を感じることなく,装置がある安心感で日ごろの不安が無く, 安心して外出できるとシステムを評価した。

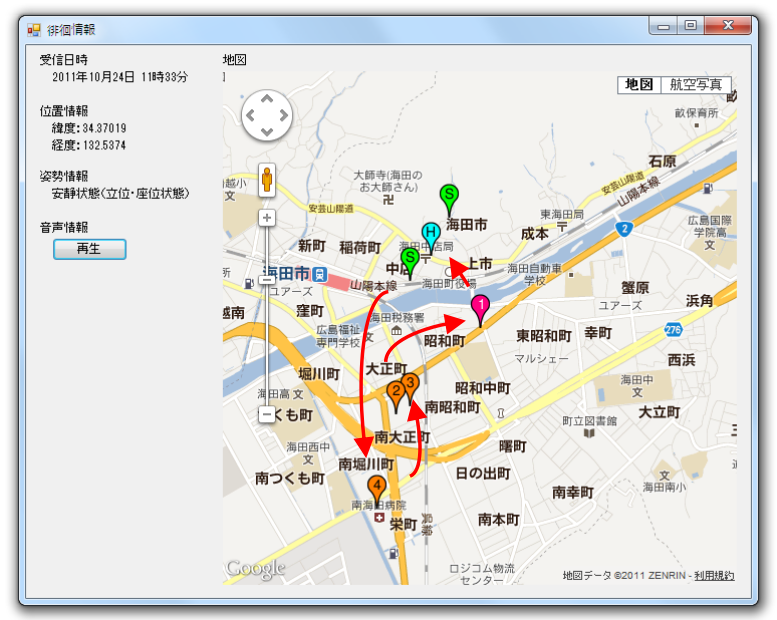

Fig.9 The subject's moving locus displayed on the server computer

\section{5. 考察}

PHSモジュールで取得した位置の最大誤差は,Table1に 示すよう公園で $206 \mathrm{~m}$ に対し, 踏切で $1295 \mathrm{~m}$ と約 6 倍と測定 場所で大きく異なっていた. 実験で位置情報を測定した位置 と踏切の周辺に設置されたPHS基地局の位置を地図から確 認すると,より近いPHS基地局が存在しているにも関わらず, 遠いPHS基地局の位置情報を取得していた.この結果は, 踏 切の周囲に建物等があるのに対し, 線路上に障害となるもの がなく見通しが良いことやPHS基地局の最大アクセス数制 限から遠いPHS基地局へ接続が振り替えられたと考えられ る.従って,PHSモジュールによる位置情報の取得において は, 徘徊高齢者周囲の建物, PHS 基地局の設置状況及び PHS基地局へのアクセス状態により誤差が生じる.この誤差 を低減させる方法とし,GPSの利用が考えられる.民生用の GPSを用いた位置の取得精度は約 $10 \mathrm{~m}$ であるが, 屋内, 高い 木の下, 車中などで精度が低下したり, 地下街や大型商業施 設内において位置情報を取得出来ない問題がある.そこで, 地上に設置したGPSで位置情報を取得し,その情報を屋内 や地下街に微弱電波で再送信するIMES ( Indoor MEssaging System) 方式26)が,宇宙航空研究開発機構で 考案され, 現在実証実験が行われている.このIMES方式が実 用化されれば,PHSモジュールより正確な位置の取得が可能 になるが,徘徊高齢者の保護を考えると, 位置情報を介護者 に通報する携帯電話などの通信装置と組み合わせる必要が
ある.そこで,本研究では,Table1に示すよう位置取得精度が GPSより劣っていても, 徘䧃状況の把握を目的に取得した環 境音で場所の推定が可能であるか検討した.しかし,Table 2 の環境音による場所の推定結果に示されるよう特徵的な環 境音が少ない公園の場合, 場所の推定は環境音を聞く被験 者個人の音の識別能力に依存し, 10 秒間の環境音再生 でも正解率 $78 \%$ であった. 一方, 環境音と位置情報を併用し た場合, Table2 に示すよう特徵的な環境音が少ない公園に おいても場所推定の正解率は100\%となり,位置情報と環境 音を用いる有効性が示された. 実験結果Fig.9で得られた位 置情報には,Table1に示すよう最大 $1295 \mathrm{~m}$ の誤差を含んで いる可能性があるが, 環境音を併用することで, 被験者が病 院やスーパーマッケットなどの場所にいることが, 被験者の家 族によって容易に把握され, 確認された.また,Fig.8(a)に示 すよう 10 分毎に得られる位置情報の履歴と道路などの地図 情報からも,被験者の移動状況が確認された.

以上,本研究における実証実験は,システムの動作確認を 主目的として,1名の被験者で行ったが, 被験者の場所や移 動状況が確認出来たことから, 提案したシステムによる徘徊 高齢者の徘徊遠隔モニタリングの可能性を示した.

\section{6. 結論}

本研究では,PHSモジュールを用いたウェアラブル徘徊高 齢者介護支援システムによる遠隔徘徊モニタリングの可能 性を示した.本システムは, 日常生活において徘徊高齢者に 装着を意識させることなく,介護者による徘徊状況の遠隔モ ニタリングを可能にし, 徘徊高齢者の介護支援と共に,介護者 の精神的負担軽減の可能性を示した.今後は, 本システムの 有効性を多くの実証実験によって明らかにしていく必要があ る.

\section{謝辞}

本研究の一部は,ちゅうごく産業創造センター平成 23 年度 新産業創出研究会「高齢者の安全生活支援行動モニタリン グ装置」によって行われていることを記すとともに関係者各 位に感謝申し上げます.また本研究に対する実証実験でご 協力いただいた有限会社スローライフ広島 ヘルパーステー ションゆず西の澤井弘美所長をはじめとする訪問介護員の 皆さま,被験者の方に感謝申し上げます。

\section{参考文献}

1）厚生労働省, ”厚生労働白書”, 2007：34.

2）三原博光, 田崎 愛子, 森しおり, “在宅における痴呆性 老人の家族が抱える問題について”, 山口県立大学看 護学部紀要, $2002 ; 6: 69-75$.

3）堀川茂野, “警察における福祉的側面について”, 法政 論叢, $2006 ; 43(1)$ : 139-157. 
4）松本 哲也, ”ユビキタスネットワークを活用した高齢者等 の安心安全を確保する見守り空間創成に関する研究開 発”, 戦略的情報通信研究開発推(SCOPE) 第6回成 果発表会, 2012：114-115.

5）青野雅樹, “介護施設内における徘徊老人の位置情報 追跡システムの研究”, 電気通信普及財団研究調査報 告書, $2009 ; 24: 576-587$.

6）山本 博美, 若松 秀俊, “施設・在宅における徘徊性老 人の電子保護システムによる安全の確保”, 医用電子と 生体工学, 1991；29(2): 97-104.

7）山本博美, 若松秀俊, ”施設における徘徊性老人用電 子保護システムの運用とその効果”, 日本健康科学学会 誌, 1993; 9(3): 182-189.

8）山本 博美, 若松秀俊, 系井 節, “個人識別可能な痴呆 性徘徊老人の電子保護システム運用と効果”, 電子情 報通信学会論文誌。D-II, 1997; J80-D-2(1): 359-362.

9）筒井譲二, 田中智幸, 中尾敏章, 和中 剛, 光武 義雄, “徘徊検知システム「徘徊コール」”, 松下電工技報, $2001 ; 2: 10-15$.

10）松野博文, 杉本 義己, 北山一郎, 宇根 正美, 小山美 代, ”徘徊看視システムの調查研究 (その2)”, 兵庫県立 福祉のまちづくり工学研究所報告集, 2003: 96-104.

11）伊藤 誠悟, 吉田 廣志, 河口信夫, “無線LAN位置推定 とGPSのシームレスな統合手法”, 情報処理学会研究 報告, 2006: 117-122.

12）五十嵐晃, 真柄 賢太郎, 野中敏, 大野宏, “GPS測位 技術を用いた俳徊老人の位置探索システム”, 電気学 会論文誌, 2006：609-616.

13）渡辺浩亘, 牧野秀夫, 北條 晴正, 石井 郁夫, “検出領 域を拡大したGPS方式徘徊老人検索システム”, 電子 情報通信学会技術研究報告. HCS, ヒューマンコミュニ ケーション基礎97, 1997；9：21-28.

14）保坂 良資，斎藤 正男，“PHSを技術基盤とする徘徊老 人定位に適した電子マーカの仕様の研究”, 電子情報 通信学会論文誌。D-II，II-パターン処理，1999; J82-D-II(12)：2367-2374.

15) Hidekuni Ogawa, Yoshiharu Yonezawa, Hiromichi Maki, Haruhiko Sato and W. Morton Caldwell, "A mobile phone-based Safety Support System for wandering elderly persons", 26th IEEE Eng Med.Biol. Soc (EMBS) Conf., 2004: 2373-2374.

16) Hidekuni Ogawa, Yoshiharu Yonezawa, Hiromichi Maki, Allen W. Hahn and W. Morton Caldwell "An Electronic Location Safety Support System” ,Biomedical Sciences Instrumentation, 43, 2007: 127-129.

17) Shingo Matsuoka, Hidekuni Ogawa, Hiromichi
Maki, Yoshiharu Yonezawa and W. Morton Caldwell, "A new safety support system for wandering elderly persons", 33th IEEE Eng Med.Biol. Soc (EMBS) Conf., 2011: 5232-5235.

18）株式会社ユビキタス，“どこ・イルカ mini”, http://www.dokoiruka.jp/, アクセス日 2011/12/27.

19） SECOM, “ココセコム”, http://www.855756.com/ag ed, アクセス日 2011/11/26.

20）鳥越 けい子，"サウンドスケープーその思想と実践"，日 本音響学会誌，1997；53(12): 964-971.

21）鳥越 けい子, "サウンドスケープが拓く音環境デザイン の新たな地平", 環境工学総合シンポジウム講演論文集, 2006; 7: 47-52.

22）藤沢 望,山口 さなえ, "長崎・五島のサウンドスケープ", 長崎県立大学 研究紀要, 2010；11：pp.31-36.

23）槇弘倫, 米沢 良治, 松岡 伸吾, 小川英邦, 佐藤 陽彦, “高齢者日常生活活動記録システム”, 医科器 械学, 2003; 11:669-676.

24) Google, Inc., “モバイル Googleマップ”, http://www. google.co.jp/mobile/maps, アクセス日2012/11/19.

25）株式会社 Nero, “NeroAAC コーデック”, http://www.nero.com/jpn/technologies-aac-code c.html, アクセス日 2012/10/20.

26）財団法人 ニューメディア開発協会, “屋内測位普及発 展に関する調查研究”，屋内測位普及発展に関する調 査研究 報告書, 2009: 13-20. 